American Journal of Pharmaceutical Education 2019; 83 (4) Article 7228.

\title{
THEME ISSUE
}

\section{Cultural Sensitivity and Global Pharmacy Engagement in the Arab World}

\author{
Naser Z. Alsharif, PhD, PharmD, ${ }^{\mathrm{a}, \mathrm{b}}$ Nile M. Khanfar, PhD, MBA, ${ }^{\mathrm{c}}$ Lisa F. Brennan, PharmD, ${ }^{\mathrm{d}}$ \\ Elias B. Chahine, PharmD, ${ }^{\mathrm{e}}$ Abeer M. Al-Ghananeem, $\mathrm{PhD},{ }^{\mathrm{f}}$ Jillian Retallick, PharmD, ${ }^{\mathrm{g}}$ \\ Mona Schaalan, $\mathrm{PhD},{ }^{\mathrm{h}}$ Neven Sarhan, $\mathrm{MS}^{\mathrm{h}}$ \\ ${ }^{a}$ School of Pharmacy and Health Professions, Creighton University Medical Center, Omaha, Nebraska \\ ${ }^{\mathrm{b}}$ Editorial Board Member, American Journal of Pharmaceutical Education, Arlington, Virginia \\ ${ }^{\mathrm{c}}$ College of Pharmacy, Nova Southeastern University, Palm Beach Gardens, Florida \\ d School of Pharmacy, Wingate University, Wingate, North Carolina \\ ${ }^{\mathrm{e}}$ Lloyd L. Gregory School of Pharmacy, Palm Beach Atlantic University, West Palm Beach, Florida \\ ${ }^{\mathrm{f}}$ Faculty of Pharmacy, Jordan University of Science and Technology, Irbid, Jordan \\ ${ }^{\mathrm{g}}$ College of Pharmacy, Nova Southeastern University, Palm Beach Gardens, Florida \\ ${ }^{\mathrm{h}}$ Faculty of Pharmacy, Misr International University, Cairo, Egypt \\ Submitted June 26, 2018; accepted August 19, 2018; published May 2019.
}

Objective. To create a resource on cultural sensitivity for schools and colleges of pharmacy that are currently engaged or considering future outreach opportunities in the Arab world.

Methods. A literature review (2000-2018) of databases and Internet searches with specific keywords and terms were conducted. Authors who had experience in travelling to and hosting students and professionals from the Arab world and authors with local work experience in the Arab world were solicited.

Results. General information about the Arab world, including unique aspects of individual countries, is presented. Stereotypes and misconceptions regarding the region and the people are discussed. Specific information about the government and infrastructure of each country, including their health care system is provided, with emphasis given to pharmacy education and practice in the region. In addition, recommendations for culturally sensitive engagement for pharmacy and other health care practitioners are discussed. Finally, recommendations for culturally sensitive engagement when hosting students and/or faculty members from the Arab world are also addressed.

Conclusion. Global engagement between schools and colleges of pharmacy in the United States and those in the Arab world is increasing. For an enriching and fruitful engagement, sensitivity toward the cultural and clinical needs of the people, and in particular, the professionals of that region is critical.

\section{INTRODUCTION}

Global engagement between schools and colleges of pharmacy in the United States and those in the Arab world is increasing. In the United States, this has been the result of many schools and colleges of pharmacy establishing a global strategic plan, embedding the curriculum with global didactic content, providing opportunities for international experiential rotations, and/or enhancing recruitment efforts to sustain operations in an increasingly competitive environment. ${ }^{1-3}$ In the Arab world, new schools and colleges of pharmacy have been established over the last

Corresponding Author: Naser Z. Alsharif, Department of Pharmacy Sciences, School of Pharmacy and Health Professions, Creighton University Medical Center, 2500 California Plaza, Omaha, NE 68178. Tel: 402-280-1857. E-mail: naseralsharif@creighton.edu several years. This has contributed to the growth of pharmacy services throughout the region, with advanced clinical practice in countries like Saudi Arabia and the United Arab Emirates. ${ }^{4-6}$ Also, the curriculum in many programs has been strengthened to meet international standards, especially those set by the Accreditation Council for Pharmacy Education (ACPE) ${ }^{7}$ and the Canadian Council for Accreditation of Pharmacy Programs (CCAPP). ${ }^{8}$ In addition, a culture of seeking certification or accreditation has resulted in many schools and colleges of pharmacy reaching out to pharmacy organizations in the United States to gain collaborative mentorship and partnership for further educational opportunities and postgraduate training. The ACPE grants certification or continuance to a professional pharmacy program in a country outside the United States that "demonstrates compliance with most or all quality criteria and meets all ACPE's requirements for such recognition." 


\section{American Journal of Pharmaceutical Education 2019; 83 (4) Article 7228.}

Historically, for reasons that will be discussed later, the Arab world has been misunderstood and misrepresented by the West, including the United States, resulting in the formation of many stereotypes and misconceptions. Thus, given the increased demand in the Arab world for health sciences education including pharmacy education, health care professionals from the United States who wish to collaborate with educators in that part of the world must be aware and sensitive to cultural, religious, historical, and political issues that may negatively impact their engagement. Thus, this paper aims to serve as a resource for schools and colleges of pharmacy that are currently engaged or considering future outreach opportunities in the Arab world, to ensure a purposeful, fruitful, and enriching experience.

\section{METHODS}

The general methodology used in conducting this study was discussed in the introduction to this theme issue of the Journal. ${ }^{10}$ Other keywords or terms used in the search included: Arab world, Middle East, names of respective countries, and orientalism. The majority of the authors are Arab-Americans who were born, graduated, taught, and/or served as visiting professors or program evaluators in the Arab world. One author is a US faculty member who practiced for several years in the region.

\section{RESULTS \\ Arab World}

The Arab world currently consists of 22 countries (Table 1) that share a common language, Arabic, in addition to a common Semitic heritage, history, and culture. ${ }^{11,12}$ This definition has been used by the United Nations Development Program, ${ }^{13}$ the Arab League, ${ }^{14}$ and other organizations to characterize the Arab world. Many people consider Iran and Turkey as part of the

Table 1. Countries in the Arab World

\begin{tabular}{ll}
\hline 1. Algeria & 12. Morocco \\
2. Bahrain & 13. Oman \\
3. Comoros & 14. Palestinian territories \\
4. Djibouti & 15. Qatar \\
5. Egypt & 16. Saudi Arabia \\
6. Iraq & 17. Somalia \\
7. Jordan & 18. Sudan \\
8. Kuwait & 19. Syria \\
9. Lebanon & 20. Tunisia \\
10. Libya & 21. United Arab Emirates \\
11. Mauritania & 22. Yemen \\
\hline
\end{tabular}

Arab nations; however, because they speak Farsi or Turkish and have separate histories, they are not considered Arab. The population of the Arab world is 422 million people. Inhabitants live in a large geographical area expanding from the southwestern area of Asia to the northern area of Africa. ${ }^{15,16}$ While Arabs are the majority, many other ethnic groups live in the region such as the Kurds in Iraq and Syria, and Armenians and Druze in Lebanon and Syria. ${ }^{15,16}$ The majority of Arabs live in cities, towns, and villages, and the region includes some of the oldest cities in the world (eg, Baghdad, Cairo, Damascus, Jerusalem). ${ }^{15}$ Approximately $90 \%$ of Arabs practice Islam, 10\% practice Christianity, and less than $1 \%$ practice Judaism. ${ }^{15,16}$ The Arab Christians (eg, $40 \%, 5 \%$, and $5 \%$ in Lebanon, Jordan, and Palestine, respectively) are among the oldest Christian communities in the world and trace their history to the time of Jesus and the disciples. ${ }^{15,16}$ Islam plays a major part in the religious, social, and political aspects of life in most countries. The peaceful coexistence of Muslims, Christians, and Jews in these countries was a model for centuries and was achieved through an emphasis on the commonalities among these three monotheistic religions. ${ }^{17}$ The Palestine-Israel conflict, the Iraq-Iran war, the Lebanese civil war, and more recently the war in Yemen and Syria, as well as external interference and the rise of radical ideologies, have resulted in frictions and violence among different religious denominations and countries. The majority of the people in the Arab world still hold on to the ideals of coexistence, resist such frictions, and are working toward mutual respect among the different religious and ethnic groups, and relations with neighboring countries. ${ }^{18}$ However, as with other regions of the world, racism and other "isms" do exist, and a more serious discussion among respective governments and the people of the region on these issues is needed.

Resources in the Arab world vary greatly between oil-producing and non-oil-producing countries. The Gulf states, also known as the Gulf Cooperation Council (GCC), ${ }^{19}$ include the following countries: Bahrain, Kuwait, Oman, Qatar, Saudi Arabia, and the United Arab Emirates (UAE). The GCC and Iraq use their oil and natural gas wealth to develop all sectors of society including education and health. ${ }^{20}$ This wealth has facilitated many global engagements in pharmacy education and practice that have resulted in significant advancements in a short period of time, which has not happened in other parts of the Arab world. Importantly, health professionals from the United States and other countries seeking opportunities for global engagement in the Arab world should also consider collaborating with countries 


\section{American Journal of Pharmaceutical Education 2019; 83 (4) Article 7228.}

such as Comoros, Djibouti, Libya, Mauritania, and Yemen, which are in dire need of developing their health care force, including pharmacists. For this review, emphasis was on countries with current, active global outreach programs, and those with published documentation about pharmacy education and practice, as well as global engagement activities. However, the needs of some other countries will be highlighted.

When interacting with the Arab world or any other region, understand its history is important. The Arab world is the birthplace of Judaism, Christianity, and Islam. The majority of residents currently living there are the descendants of Arabs who accepted Islam and spread it as far as China to the east and Spain and North Africa to the west. $^{21}$ The Islamic civilization $\left(8^{\text {th }}-14^{\text {th }}\right.$ centuries $)$ developed many advancements in science, medicine, pharmacy, mathematics, and astrology. ${ }^{22,23}$ The Crusades $^{24,25}$ and more recently animosity from betrayal in World War I after the collapse of the Ottoman Empire $\left(14^{\text {th }}-20^{\text {th }}\right.$ centuries $),{ }^{26,27}$ colonialism, ${ }^{27-29}$ and the establishment of Israel on the land of Palestine by the British, created the basis of mistrust of the West among Arab countries that continues to some extent today. ${ }^{25}$ Although the colonial era led to development in some countries, it also contributed to foreign control of the economy of many Arab countries for decades, creating an elitist society, and established arbitrary borders and constitutional distribution of power leading to later wars such as the Iraq-Iran war ${ }^{30}$ and the civil war in Lebanon. ${ }^{31}$

Most Arab countries obtained independence by the middle of the $20^{\text {th }}$ century with establishment of secular governmental systems in some countries and a rise in Arab nationalism. ${ }^{29,32}$ The Arab League was established in 1945 to address the interests of the Arab people. ${ }^{14}$ However, for the remainder of the $20^{\text {th }}$ century and the beginning of this century, the Arab world struggled with corruption, dictatorships, and lack of resources in some countries. ${ }^{33,34}$ Also, wars and instability made it difficult to unlock the great potential of many countries. The September 11, 2001 terrorist attack on the United States, and the resulting "war on terrorism" have created more tension between Arab countries and the West and hate crimes against Arabs and Muslims in the United States. ${ }^{35-37}$ The Arab Spring, starting with the Tunisian Revolution in 2010 and spreading to six other countries including Bahrain, Egypt, Libya, Syria, Sudan, and Yemen, reignited hope for transitioning the Arab world into a new era of democracy. However, internal factors and external interference have stalled these efforts. ${ }^{38}$ Despite these hindrances, those working in education, health care systems, and other sectors of society in the Arab world continue to pursue higher standards and international quality assurance in their field. This is driven by the increased number of college graduates from local and international universities. Colleges in Egypt, Iraq, Jordan, Lebanon, Palestine, and Syria have graduated thousands of health care professionals. In turn, these graduates have contributed to the betterment of health sciences education and health care systems in other parts of the Arab world such as in the GCC countries. ${ }^{39,40}$ Because of instability in the region, many professionals have migrated to the West in search of better opportunities. ${ }^{39,40}$ However, the number of new university graduates continues to grow. The wealth and breadth of knowledge that many of these graduates have is challenging the status quo. Many governments in the Arab world recognize the need to create more job opportunities for these graduates.

Language. Arabic is the official language of all countries in the Arab world and the Arab league and is one of the six official languages of the United Nations. Arabic is a Semitic language and, depending on the source, ranks between third and sixth in the world in number of native speakers. ${ }^{41}$ There are four main regional dialects of Arabic: Egyptian, Iraqi/Gulf, Levantine (Jordan, Lebanon, Palestine, Syria), and Magreb (North Africa). Numerous variations in these dialects exist. ${ }^{42}$ In addition, several other languages such as Kurdish and Berber are spoken in small areas throughout the Arab world. ${ }^{42}$ Arabic text is written in the Arabic alphabet, from right to left. This alphabet contains 28 consonants and three vowels, although only long vowels are written. ${ }^{43}$ This can lead to many translations, with the same word spelled several ways in English based on its pronunciation (eg, Koran, Quran, and Qu'ran; Mohammed, Muhamad, and Mohamad; Muslim and Mozlem). Through the Quran, over 1.5 billion Muslims throughout the world learn at least basic Arabic for worship. Calligraphy in Arabic is considered an art form. Despite the official status of Arabic, English, and, to a lesser extent, French remain the languages of higher education (including in pharmacy education) and health care documentation in most countries.

Transportation. The types of available transportation within and between the different countries of the Arab world is variable. For the most part, transportation within major cities is well established. However, urban planning is difficult in some ancient cities such as Amman, Beirut, Cairo, and Damascus, because of the age of the infrastructure. Modern streets and highways, including cross-country highways, exist in the majority of Arab countries. Some countries such as Egypt have extensive railroad systems, and Cairo has an underground metro system. ${ }^{44}$ The newly established GCC States have a more organized and advanced transportation system with spacious highways, smart city plans, and traffic apps. ${ }^{45,46}$ 


\section{American Journal of Pharmaceutical Education 2019; 83 (4) Article 7228.}

While transportation network companies and taxi services are available in many countries, bus services vary. Because of heavy traffic in urban areas, driving can be very challenging in countries such as Egypt, Jordan, Lebanon, and Syria, and is not recommended for firsttime visitors. ${ }^{47,48}$ Speeding and aggressive driving is a problem in most Arab countries, with some countries having the highest traffic death rates in the world. However, in recent years, local rules against speeding and aggressive driving are becoming more stringent. ${ }^{49,50}$

Diet. The Arab diet consists of a healthy Mediterranean diet. Breakfast includes local and imported cheeses, olives, olive oil and thyme, humus, Ful medames (ie, Vicia faba), falafel, and boiled eggs. Rice, lamb meat, pita bread, and cooked vegetables are also common. ${ }^{51,52}$ Many traditional dishes are available in most Arab countries such as kebab, Jordanian and gulf states mansaf; Palestinian musakhan, Lebanese tabouli, Moroccan couscous, and stuffed cabbage and eggplant. ${ }^{51-53}$ Fruits as well as sweets such as baklava and kenafeh are also commonly served after meals. Offering food to guests is a common practice, as is insisting they have second and third servings. Visitors to Arab countries should be aware and sensitive of such traditional hospitality practices. In addition to local cuisine, most Arab countries have restaurant franchises from many Western European countries as well as those from the United States. Indian, Chinese, Italian, and, to a lesser extent, Mexican and French restaurants are also present in most countries. Pork products are not available in most Arab countries because of Islamic teachings. While sale of alcohol is permitted in some countries such as Jordan, Lebanon, and the UAE, it is prohibited in other countries such as Saudi Arabia. Visitors should be aware of local rules and regulations regarding alcohol and follow them.

Safety. Safety in all global engagements is imperative, and that is no different for the Arab world ${ }^{54-56}$ However, the sensationalist way in which some Western media outlets portray the Arab world makes many in the West reluctant to engage in outreach activities in the region because of safety concerns. For the majority of the countries in the Arab world, it is safe to travel, and visitors usually have pleasant and fulfilling experiences. ${ }^{57}$ However, caution should be exercised when engaged with countries where there is conflict and increased political tension, such as is currently the case in Iraq, Libya, Palestine, Syria, and Yemen. Prospective visitors should access the US State Department website to check on travel advisories before making any travel plans. ${ }^{58}$

Status of Women. Arab women in general and Muslim women in particular are portrayed in a negative way in Western media including in the United States. However, in many Arab countries, especially in Egypt, Jordan, Lebanon, Palestine, and Tunisia, women have historically been well integrated into the fabric of society and all its sectors. ${ }^{59}$ Many hold higher professional and leadership positions such as deans and directors of pharmacy. ${ }^{60,61}$ However, women's rights remain as much of an issue as in many other parts of the world. ${ }^{59,60}$ While Islam is blamed for some of the restrictions on women in the Arab world, since its inception, Islam has recognized the full personhood of women. Islam also established a woman's right to choose a husband, have an inheritance, own property, and pursue an education. Islam recognizes that marriage is a contract between a man and a woman, and as such, the woman's consent to marry is required..$^{21}$ The restrictions and discrimination that women often face emanate from cultural and political factors. For example, in Saudi Arabia a woman is required to cover her entire body, and there is a separation of men and women in education and in many aspects of the public domain. However, most Arab countries do not impose these limitations. ${ }^{62}$ Overall, modesty for both Muslim and Christian men and women is a virtue that is promoted in most Arab countries based on religion and tradition.

Health Care System. Health care systems in the Arab world have advanced in a number of countries in the last 20 years, with increased access to all sectors of health care including governmental and private hospitals, ambulatory care clinics, pharmacies, and dental clinics. ${ }^{63}$ In Abu Dhabi, Dubai, and Qatar, state of the art hospitals were recently completed. ${ }^{64}$ In July 2017, the Dubai Health Authority announced that it will open 12 new private hospitals by $2020 .^{65}$ This expansion of health care has increased the region's attractiveness for medical tourism. Egypt, Jordan, and Lebanon have been destinations for health tourism for many years, with some of the Gulf States now working to increase their share of the health tourism market. ${ }^{66-69}$ In 2016, Dubai launched the world's first medical tourism portal with a goal of attracting over 500,000 international medical tourists. ${ }^{70}$ The wars in Libya, Syria, and Yemen have created an influx of patients seeking medical care. The medical expertise, desirable weather, and somewhat conservative societies made countries such as Egypt, Jordan, and Lebanon a perfect destination for many patients from these countries and the GCC in general.

Bahrain has a universal health care system that is free of charge to Bahraini citizens and subsidized for nonBahrainis. $^{71}$ Health care expenditure accounted for $4.5 \%$ of Bahrain's gross domestic product (GDP), according to the World Health Organization. ${ }^{72}$ Similar to all GCC countries, the Kuwaiti government offers its citizens free medical treatment at government facilities. The 


\section{American Journal of Pharmaceutical Education 2019; 83 (4) Article 7228.}

Ministry of Health $(\mathrm{MoH})$ strictly controls the price of medications in pharmacies, which eliminates the need to go from pharmacy to pharmacy to find lower prices. ${ }^{73}$ The health care in Oman has significantly improved after the MoH was established in 1976. Most of the country's medical staff are foreigners; however, this is changing rapidly as the government is employing new policies to encourage its own citizens to work in the medical field. ${ }^{74}$ Health care in Qatar is regarded as being one of the highest quality in the region. ${ }^{75,76}$ Health care is free for nationals, but expatriates (an expatriate is a person who resides outside their native country) have the option of obtaining a state insurance card. Recently the government has made treatment of cancer for expatriates $100 \%$ free of charge, which is considered unprecedented in the rich gulf region. ${ }^{75-77}$ The health care system in Saudi Arabia is also considered of high quality. ${ }^{78-80}$ Private health insurance is essential as most private hospitals and clinics with high standards are expensive. In contrast, public hospitals are usually free. ${ }^{78-80}$ In the UAE, over $50 \%$ of the 2017 budget allocation went toward social services, of which $8.6 \%$ was allocated to health care. ${ }^{81}$ The country is rolling out a compulsory health insurance program for expatriates, particularly in Dubai. ${ }^{82}$ For citizens, medical care is free of charge. ${ }^{81-83}$ The private health care sector has risen significantly in recent years and will continue to drive growth in the country. Currently, only GCC nationals are permitted to use governmental pharmacies which offer drugs at lower prices than privately owned pharmacies. ${ }^{81,82}$

Jordan has one of the most modern health care infrastructures in the Arab world, with almost $63 \%$ of Jordanians being insured. ${ }^{84,85}$ Jordan hospitals are mainly those of the $\mathrm{MoH}$ and the Royal Medical Services. ${ }^{84}$ Other smaller public hospitals include several university-based programs, such as Jordan University Hospital in Amman and King Abdullah Hospital in Irbid. The advanced health care services in Jordan have led to its ranking as the number one medical tourism provider in the Arab region and among the top five in the world, as well as the top medical tourism destination in the Middle East and North Africa ${ }^{66}$ In Lebanon, the quality of health care varies between the public and the private sectors with the latter (eg, American University of Beirut Medical Center $^{86}$ and the Hotel Dieu de France ${ }^{87}$ ) providing better quality health care at a higher cost.

Drug Regulations. The majority of the health sectors in the Arab world are overseen by a MoH. However, with the exception of the UAE, all the countries examined have their own regulatory authority which monitors and controls the pharmaceutical and food industry (Table 2), ${ }^{88,89}$ similar to the US Food and Drug Administration. The health care industry in the UAE is regulated by a $\mathrm{MoH}$ with further oversight in the Emirate of Dubai by its respective agency. ${ }^{90}$ In Kuwait, the Kuwait Drug and Food Control Administration is the main regulator of quality and safety of medications, herbal products, dietary supplements, and medicated cosmetics. ${ }^{91}$ The Directorate General of Pharmaceutical Affairs and Drug Control is the regulative authority of Oman. ${ }^{92}$ It is accountable to ensure the drugs in Oman are safe, effective, and of high quality, whether manufactured for local use or exportation. The Saudi Food and Drug Authority (SFDA) is responsible for regulating medications, food, cosmetics, and electronic products in Saudi Arabia. Like the other administrations, its main mission is to ensure the safety, quality, efficacy, and accessibility of these products to the public. ${ }^{93}$ Finally, in the UAE, pharmacy and supplies are regulated by several departments within the $\mathrm{MoH}$, and medications must be registered before they can legally be imported into the country. ${ }^{90}$

In general, the regulations referring to drug dispensing are comparable to those of the West; however, the laws are not strictly enforced in community pharmacies. For example, in many countries in the Arab world, despite efforts by the $\mathrm{MoH}$ to curb this behavior, patients can still procure medications without a prescription, with the exception of narcotics and major tranquilizers.

\section{Pharmacy Education}

Over the last 20 years, there has been significant growth in the number of schools and colleges of pharmacy in many countries in the Arab world. Table 3 lists schools and colleges of pharmacy in the region that have obtained international accreditation (eg, Doctor of Pharmacy program at the Lebanese American University, the only fully ACPE-accredited program outside the United States ${ }^{94}$ ) or certification for their programs through ACPE and CCAPP. ${ }^{94,95}$ In general, pharmacy education quality in the Arab world is regulated and maintained by the Ministry of Higher Education through accreditation by each country's respective national authority for quality assurance and accreditation of education.

Pharmacy education in Palestine presents a story of challenges and successes because of the Palestine-Israel conflict. However, since the establishment of the bachelor's degree in pharmacy at Al-Azhar University in Gaza in $1992,{ }^{96}$ five more schools and colleges of pharmacy have been founded. Iraq had an excellent education system, including pharmacy education, before the Iraq-Iran War and the US invasion. Iraq is now trying to restore the integrity of its educational institutions. ${ }^{97}$ In 2016, Egypt had 44 pharmacy schools affiliated with governmentally 
American Journal of Pharmaceutical Education 2019; 83 (4) Article 7228.

Table 2. Differences in Regulatory Agencies Among Some Arab Countries ${ }^{88,89}$

\begin{tabular}{|c|c|c|c|}
\hline Country & Agency that Regulate Pharmaceuticals & $\begin{array}{c}\text { Agency that Oversees Health } \\
\text { Care and Pharmacy }\end{array}$ & Regional Affiliations \\
\hline$\overline{\text { Algeria }}$ & $\begin{array}{l}\text { Direction de la Pharmacie et du } \\
\text { Medicament }\end{array}$ & $\begin{array}{l}\text { Ministere de la Sante, de la } \\
\text { Population et de la Reforme } \\
\text { Hospitaliere }\end{array}$ & \\
\hline Bahrain & National Health Regulatory Authority & Ministry of Health & \\
\hline Djibouti & $\begin{array}{l}\text { Direction du Medicament et de la } \\
\text { Pharmacie }\end{array}$ & Ministere de la Sante & \\
\hline Egypt & Egyptian Drug Authority & Ministry of Health and Population & \\
\hline Jordan & Jordan Food and Drug Administration & Ministry of Health & $\begin{array}{l}\text { Asian Harmonization } \\
\text { Working Party }\end{array}$ \\
\hline Kuwait & $\begin{array}{l}\text { Kuwait Drug and Food Control } \\
\text { Administration }\end{array}$ & Ministry of Health & $\begin{array}{l}\text { Asian Harmonization } \\
\text { Working Party }\end{array}$ \\
\hline Lebanon & Ministry of Public Health & Ministry of Public Health & \\
\hline Morocco & $\begin{array}{l}\text { Direction du Medicament et de la } \\
\text { Pharmacie }\end{array}$ & Semi-autonomous & \\
\hline Oman & $\begin{array}{l}\text { Directorate General of Pharmaceutical } \\
\text { Affairs and Drug Control }\end{array}$ & Ministry of Health & \\
\hline $\begin{array}{l}\text { Palestinian } \\
\text { Territories }\end{array}$ & General Directorate of Pharmacy & Ministry of Health & \\
\hline Qatar & Pharmacy and Drug Control & Supreme Council of Health & \\
\hline Saudi Arabia & Saudi Food and Drug Authority & Ministry of Health & $\begin{array}{l}\text { Asian Harmonization } \\
\text { Working Party }\end{array}$ \\
\hline Somalia & Pharmaceutical and Medical Department & Ministry of Health & \\
\hline Yemen & $\begin{array}{l}\text { Supreme Board for Medicine and Medical } \\
\text { Appliances }\end{array}$ & Ministry of Public Health & $\begin{array}{l}\text { Asian Harmonization } \\
\text { Working Party }\end{array}$ \\
\hline
\end{tabular}

and privately funded universities. Sixteen thousand students were admitted to the Bachelor of Pharmacy (BPharm) degree programs and several hundred to postgraduate degrees. ${ }^{98}$

While the Bachelor of Science (BS) degree is offered by a majority of schools and colleges of pharmacy in the Arab world, the PharmD is now being introduced as the entry-level professional degree program at many institutions. However, in general, there is a shortage in the number of clinical faculty members who are qualified to teach clinical courses and precept students, as well as faculty members who teach social and administrative courses. ${ }^{99}$ Efforts in many Arab countries are underway to provide for such expertise, especially in Egypt, Jordan, and the
Gulf States. One encouraging aspect of pharmacy education is the motivation of the students and the increased activities of student pharmacy organizations over the last few years. While some do take on a political role, many are becoming more involved in community service activities and professional advocacy. ${ }^{100}$ Thus, global engagement activities should strengthen the role such student organizations can play.

\section{Postgraduate Pharmacy Education and Training}

Graduate pharmacy education at the level of MS and $\mathrm{PhD}$ programs are available in several countries in the Arab world. Currently, there are also residency programs accredited by the American Society of Health-Systems 
American Journal of Pharmaceutical Education 2019; 83 (4) Article 7228.

Table 3. Pharmacy Programs with International Accreditation or Certification Status ${ }^{7,8}$

\begin{tabular}{|c|c|c|c|c|}
\hline Country & $\begin{array}{c}\text { Name of University with } \\
\text { School or College of Pharmacy }\end{array}$ & $\begin{array}{c}\mathrm{ACPE}^{\mathrm{a}} \\
\text { Accreditation }\end{array}$ & $\begin{array}{c}\mathrm{ACPE}^{\mathrm{a}} \\
\text { Certification }\end{array}$ & $\begin{array}{c}\text { CCAPP }^{\mathrm{b}} \\
\text { Accreditation }\end{array}$ \\
\hline \multirow[t]{2}{*}{ Lebanon } & $\begin{array}{l}\text { Lebanese American } \\
\text { University }\end{array}$ & $\mathrm{X}$ & & \\
\hline & Beirut Arab University & & & $\mathrm{X}$ \\
\hline Jordan & University of Jordan & & $\mathrm{X}$ & \\
\hline \multirow[t]{4}{*}{ Saudi Arabia } & King Faisal University & & $\mathrm{X}$ & $\mathrm{X}$ \\
\hline & King Saud University & & $\mathrm{X}$ & $\mathrm{X}$ \\
\hline & Qassim University & & $\mathrm{X}$ & \\
\hline & $\begin{array}{l}\text { King Abdulaziz } \\
\text { University }\end{array}$ & & & $\mathrm{X}$ \\
\hline $\begin{array}{l}\text { United Arab } \\
\text { Emirates }\end{array}$ & Al-Ain University & & $\mathrm{X}$ & \\
\hline Qatar & Qatar University & & & $\mathrm{X}$ \\
\hline
\end{tabular}

Pharmacists (ASHP) in Lebanon, Qatar, Saudi Arabia, and the UAE. ${ }^{101}$ Many other sites are seeking such accreditation. Other programs such as The University of Jordan and Jordan University for Science and Technology have a master's level training program. ${ }^{102,103}$ The Hotel-Dieu de France Medical Center and the American University of Beirut Medical Center in Lebanon have established pharmacy residency programs, with the latter seeking accreditation from ASHP. ${ }^{87}$ In addition to the PharmD degree now available in many countries in the area, several additional credentials are available to recognize pharmacists with clinical training. In Saudi Arabia, pharmacists who complete both a postgraduate year 1 (PGY1) and PGY2 residency program and have three years of experience can become licensed as a consultant pharmacist. ${ }^{104}$ In Iraq, a pharmacist can earn a clinical masters or doctorate and can be certified by the Iraqi Board of Clinical Pharmacy. ${ }^{97}$

\section{Pharmacy Practice}

The practice of pharmacy is as diverse in Arab countries as it is elsewhere throughout the world. A well-researched summary of education and practice in several of these countries was published in $2006^{105}$ and another in $2009 .{ }^{5}$ There is wide variability in patients' access to pharmacists throughout the region, as reflected by the number of pharmacists per 10,000 people in a country's population (Table 4). ${ }^{106}$ Within each country, most pharmacists work in the private sector, with a large majority employed by community pharmacies. For example, in Jordan, 91\% of pharmacists work in private community or hospital pharmacies and private industry. ${ }^{107}$ In Egypt, 65\% work in community pharmacies and another $12 \%$ in industry or other non- hospital areas. ${ }^{108}$ Community pharmacies throughout the region are widely available and many are open 24 hours a day, including hospital pharmacies. In the Gulf States, a majority of the pharmacists are expatriates who work mainly in the less lucrative community setting, while pharmacists who are citizens primarily work in the hospital setting where clinical pharmacy services are rapidly developing. ${ }^{5,109}$ This correlates with the increase in educational opportunities in the region. These countries have strategic plans for health care development in place that call for the nationalization of clinical personnel. In 2012, the SFDA stated an ambitious goal

Table 4. Number of Pharmacists per 10,000 People per Country ${ }^{106}$

\begin{tabular}{|c|c|c|c|}
\hline Country & $\begin{array}{c}\text { Number of } \\
\text { Pharmacists } \\
\text { per 10,000 } \\
\text { People in } 2015\end{array}$ & Country & $\begin{array}{c}\text { Number of } \\
\text { Pharmacists } \\
\text { per } 10,000 \\
\text { People in } 2015\end{array}$ \\
\hline Lebanon & 17.5 & Mauritania & 3.51 (2009) \\
\hline Jordan & 13.5 & Egypt & 3.4 \\
\hline Syria & 12.7 & Iraq & 2.4 \\
\hline $\begin{array}{l}\text { Palestinian } \\
\text { territories }\end{array}$ & 9.7 & Iran & 2.3 \\
\hline Qatar & 9.4 & Tunisia & 2.3 \\
\hline Kuwait & 9.0 & Djibouti & 2.2 \\
\hline $\begin{array}{l}\text { Saudi } \\
\text { Arabia }\end{array}$ & 7.5 & Yemen & 1.0 \\
\hline Bahrain & 5.8 & Morocco & 0.1 \\
\hline Oman & 5.1 & Somalia & $0.1(2008)$ \\
\hline Sudan & 4.5 & Algeria & $\mathrm{n} / \mathrm{a}$ \\
\hline $\begin{array}{c}\text { United Arab } \\
\text { Emirates }\end{array}$ & 4.0 & Comoros & $\mathrm{n} / \mathrm{a}$ \\
\hline
\end{tabular}




\section{American Journal of Pharmaceutical Education 2019; 83 (4) Article 7228.}

to nationalize all pharmacists in the Kingdom within the next 17 years. ${ }^{109}$

Clinical pharmacy practice throughout the Arab region varies from relatively well-established and wellsupported clinical practice in Saudi Arabia and UAE, to less-supported in Egypt, Jordan, and Lebanon, ${ }^{107,108,110}$ to almost non-existent in Yemen. ${ }^{111}$ However, the practice of clinical pharmacy in Lebanon and in many countries in the Arab world is gaining traction, particularly at academic medical centers and mostly in collaboration with practice faculty members at schools and colleges of pharmacy. ${ }^{112}$

Most of the clinical services are limited to the hospital setting, although the good pharmacy practice initiatives of the Jordan Pharmaceutical Association and the Qatari National Health Strategy Program have stressed the training and development of community pharmacist clinical skills. ${ }^{107,113}$ Some pharmacists in the region have pursued additional clinical credentials, with many earning certifications from the US Board of Pharmacy Specialties (Table 5). ${ }^{114}$

The Egyptian government in 2012 issued a ministerial decree requiring the practice of clinical pharmacy in hospitals as a prerequisite for hospital licensure, and in 2014 guidelines and standards for clinical pharmacy in hospitals were released. ${ }^{108}$ Saudi Arabian health care institutions are able to grant prescriptive authority to nonphysicians within the scope of their practice, ${ }^{109}$ and anecdotally have done so for pharmacists in areas such as anticoagulation and pharmacokinetic monitoring. In the UAE, the MoH has been open to discussion about expanded scope of practice for pharmacists driven mainly by the Cleveland Clinic of Abu Dhabi ${ }^{115}$ and modeled after the US standard for clinical practice. Pharmacists in Kuwait are progressively taking part in interdisciplinary teams along with physicians and even more so in

Table 5. Total Number of Board of Pharmacy SpecialtiesCredentialed Pharmacists per Country ${ }^{114}$

\begin{tabular}{lclc}
\hline Country & $\begin{array}{c}\text { Number of } \\
\text { Certified } \\
\text { Pharmacists }\end{array}$ & Country & $\begin{array}{c}\text { Number of } \\
\text { Certified } \\
\text { Pharmacists }\end{array}$ \\
\hline Egypt & 875 & Jordan & 20 \\
Saudi & 418 & Oman & 7 \\
$\quad$ Arabia & 177 & Bahrain & 6 \\
United Arab & & & \\
$\quad$ Emirates & 86 & Iran & 3 \\
Qatar & 33 & Iraq & 2 \\
Kuwait & 23 & Palestinian & 1 \\
Lebanon & & territories & \\
& &
\end{tabular}

conducting evidence-based research. ${ }^{116}$ However, surveys of pharmacists in Kuwait indicate that clinical pharmacy services are not as advanced as they could be, because of lack of policy or physician support, and need for further pharmacist training. ${ }^{117}$ Yemen is in need of more regulations as $90 \%$ of those working in pharmacies are either not pharmacists or graduated from unrecognized programs of pharmacy. ${ }^{111}$ No published articles in English on pharmacy practice in Djibouti, Mauritania, or Arab countries in Western North Africa were found. Overall, the practice of pharmacy in this region is advancing slowly in areas of current or recent conflict such as Yemen, but inexorably forward in most other countries. Further growth is needed in clinical practice, particularly in the community setting.

The pharmaceutical industry is strong in many countries, with more than 200 pharmaceutical manufacturers located in the Arab world. ${ }^{18,119}$ Pharmaceutical sales in the Middle East and North Africa account for 2\% of global pharmaceutical sales. ${ }^{118}$ Most of the pharmaceutical manufacturers are located in Egypt, Jordan, Lebanon, and Saudi Arabia ${ }^{118}$; however, the UAE's $\mathrm{MoH}$ announced plans to increase the number of generic drug manufacturing facilities in that country to 30 by $2020 .{ }^{120}$ Jordan is ranked as the number one exporter of pharmaceuticals among Arab countries. ${ }^{118}$ Saudi Arabia has the largest market for pharmaceutical consumption in the $\mathrm{GCC}^{121}$ and the Middle East. The pharmaceutical industry is expected to continue to expand with demands for better care and increased government health care spending. ${ }^{122}$ Many multinational corporations are partnering with regional companies, establishing local manufacturing.

\section{Professional Pharmacy Organizations}

While pharmacy organizations have been established in many countries in the Arab world, ${ }^{123}$ professional organizations in the region, including pharmacy organizations, tend to take on a political nature at the education and practice levels, especially in countries like Egypt, Iraq, Jordan, Lebanon, Palestine, and Syria. More recently, effort is being spent by pharmacy organizations in the aforementioned countries and especially in the GCC countries to take on a more professional role. ${ }^{124-126}$ Thus, global engagement at the education and practice levels should encourage a more professional and active role for such organizations to improve the quality of pharmacy education and practice, provide opportunities for continuous professional development, address regulations which impede the role pharmacists can play in the health care system and health of the society, and deliver proactive advocacy at the level of ministries of 


\section{American Journal of Pharmaceutical Education 2019; 83 (4) Article 7228.}

health, labor, and education. More recently, professional organizations in many countries have started to hold annual and biannual pharmacy conferences, with local, regional, and international attendance, at which professional presentations are given on many aspects of pharmacy education and practice. ${ }^{124-129}$

\section{Stereotypes and Misconceptions}

Orientalist View. The Orientalist view of the Arab world persists both in public attitudes and in academic literature. The landmark work on Orientalism was a book published by Edward W. Said in $1978^{130}$ in which he examines the representations of Eastern peoples and cultures by the West and the definition of orientalism. His ideas permeate the literature on Arab stereotypes, with his description of the orientalist representation of Muslim societies as negative and more backward than modern European societies in aspects of culture, politics, and social interaction. ${ }^{130} \mathrm{He}$ contends that this depiction has created an inferiority complex among Arabs when interacting with the West. Based on his study of the media, J. G. Shaheen proposed four major misconceptions regarding Muslims and Arabs: they are astoundingly wealthy, they are barbarians and uncultured, they are sex maniacs with a penchant for white slavery, and they revel in acts of terrorism. ${ }^{131} \mathrm{He}$ and others have documented that the region is also portrayed as an oil-rich desert run by dictators, the people are seen as uncivilized and all thought to be Muslim; the women are oppressed, veiled, and uneducated; and the men are dominating and terrorists. ${ }^{131-137}$

A study of the effects of the Orientalist view on biomedical literature published in 2007 by L.D. Laird and associates found several latent themes related to Islam. ${ }^{138}$ The first theme was that being Muslim meant one was in particular need of intervention because strict adherence to Islam posed health risks, and that maintaining traditions adversely affected Muslims so they should modernize. Negative perceptions of Muslims as uneducated, oppressed, fatalistic, and traditional contribute to this theme. The next theme was that Islam itself creates obstacles to health care, with conflicts between religious practices and medical treatment seen as noncompliance or obstructivism. The examples given are of fasting during Ramadan and strict adherence to gender roles. The study does offer one positive theme: that practicing Islam could promote good health if a person was truly adherent, leading to less substance abuse; fewer penile, cervical and breast cancers; and other positive health effects resulting from Islamic dietary and spiritual practices. The conclusions drawn were that the scientific literature often sees Muslims as a homogeneous group who are different, in- ferior, and in need of intervention. Although some literature attempts to move beyond these stereotypes, the views are far from balanced. ${ }^{138,139}$

Even the nomenclature of the region is subject to the Orientalist view. The question arises as to the difference between the Middle East and the Arab world, but the Middle East is a Eurocentric appellation solely geographically defined. Instead, as previously mentioned, Arab signifies a pan-ethnic group that share a common language, culture, and history. Depending on the geographical boundaries used to define the Middle East, between $50 \%$ to $80 \%$ of Middle Easterners are Arab. ${ }^{134,135,137}$

\section{Recommendations for Culturally Sensitive Engage- ment for Pharmacy and Other Health Care Profes- sionals}

Purposeful Engagement. One of the most critical aspects of global engagement is to ensure that it is purposeful. Thus, engagements should be needs based. In unpublished data from several pharmacy deans of Arab universities, clinical training and expertise in teaching therapeutics, social, and behavioral sciences, and pharmaceutics were identified as their main areas of need. Thus, collaborative efforts should address these identified needs. Other countries with lack of resources would benefit from more outreach activities in education and research to promote clinical pharmacy practice. ${ }^{140}$ Respect for the local culture is important in all patient interactions; thus, cultural sensitivity in the continuum of cultural competency is required. ${ }^{141}$ For example, in areas where traditional medicine is used, listening to the patient about why he/she thinks traditional medicine is the right therapy, explaining to him/her how modern medicine helps in treating disease, acknowledging the patient's input regarding traditional medicine and his/her experience with it, recommending a course of treatment based on evidence, and negotiating an action plan are critical to achieving optimal outcomes. ${ }^{142}$

Religion. Religion plays a major role for both Muslims and Christians in the Arab world. ${ }^{134,135}$ In the case of Islam, respect for religious practices such as the need to pray five times per day and fasting during the month of Ramadan is vital. ${ }^{139,143-145}$ While this practice varies among countries, in Saudi Arabia, people stop everything at the time of prayer. Similarly, eating food in public during the month of Ramadan is strongly discouraged. In general, understanding the impact of religion on health and healing beliefs is an important aspect of practice in the Arab world. ${ }^{143-145}$ The Arab Christian communities have become accustomed to the common culture, although religious practices do vary between the Coptic Orthodox Church of Alexandria in Egypt, the Greek Orthodox 


\section{American Journal of Pharmaceutical Education 2019; 83 (4) Article 7228.}

Church of Antioch in Syria, and the Maronite Catholic Church in Lebanon. ${ }^{146}$

Family Role. The importance of family in the Arab culture cannot be overstated. ${ }^{134,135,147}$ Family has always been viewed as a source of security and empowerment because of the extended support it provides. Greetings almost always include asking about family members, and it is not uncommon for extended family members to live together. ${ }^{134,135,147}$ This culture holds on to its patriarchal roots, especially in rural areas, with the oldest male having responsibility for the entire family. Whether this happens to be the father or the eldest son, he must provide for and protect his family. ${ }^{134,135,147}$ In most countries, younger women depend on their grandmothers and mothers during childbirth and for childcare. Unlike in modern Western societies, in the Arab world, young adults stay at home until they are married, and the family cares for the elderly instead of placing them in a health care facility. Resources for long-term care are minimal to nonexistent in most Arab countries. ${ }^{148,149}$ However, there have been increased efforts in some countries to provide these resources. ${ }^{148,149}$

A patient's family members are extensively involved in all health care decisions, including whether to tell the patient about their diagnosis or prognosis. Advanced directives are often foreign concepts for Muslims, as death is seen as God's will and not their place to interfere with His plan. ${ }^{144,145,150}$ Thus, depending on religious convictions, some families may be reluctant to withdraw care or provide extreme measures. In some countries and especially in rural areas, a woman may believe that her family, husband, or physician knows best, so she often lets them make health care management decisions on her behalf. Al-Amoudi emphasizes how Saudi health rules and regulations do allow for women with the mental capacity to make their own health decisions and that all stakeholders should be educated about these rules so that delay in therapy does not occur and patients are not harmed. ${ }^{151}$

Historically, mental health care was confined to the immediate and extended family. People with mental illness and their families were often looked down upon, rejected, and secluded; therefore, these illnesses were kept secret from nonfamily members, including physicians and mental health professionals. ${ }^{152}$ However, this culture is changing, and families, especially those in urban areas, will seek medical support for mental illness. While more recently some improvements in services and efforts to increase awareness have occurred, most countries still do not allocate enough expenditures and lack the professional human resources to meet the needs of patients with mental health issues. ${ }^{152}$ Thus, mental health is an important potential area to target in global engagement activities.

Gender Issues. Arab Muslim women are diverse in their adherence to religious and cultural traditions, with the vast majority adhering based on personal convictions but in some countries based on family pressure and governmental rules. However, many Arab women, especially in major cities in Egypt, Lebanon, and other countries, are more secular in their actions, behaviors, beliefs, and dress. ${ }^{153}$ Over the last several years, women's education has flourished, with women majoring in all fields ${ }^{154-156}$ as well as with women gaining the right to vote and run for office. ${ }^{157-159}$ However, further efforts are needed to ensure equal opportunities between men and women. ${ }^{154-156}$

Generally, in terms of health, modesty and privacy are valued by Arab women. Some Arab women, like their counterparts in many parts of the world, would prefer same sex care providers if possible, especially in obstetrics and gynecology. Also, they may avoid unnecessary touching of the opposite sex, eg, patting, hugging or handshaking, especially those women who are religiously inclined. ${ }^{144,145,160}$ For health care professionals, it is critical to avoid misconceptions and stereotyping of Arab women based on an orientalist view that depicts them as fragile, sexually and socially oppressed, and lacking the ability to represent themselves.

Health and Healing Practices. For many people in the Arab world, health beliefs may come down to: "medicine only goes so far, then comes God," and when it comes to health and healing, "prevention is the best cure."144,145,161-164 Such beliefs are influenced by Islam. ${ }^{161-163}$ A holistic approach to health is prevalent where physical, emotional, and spiritual health cannot be separated. Thus, prayers and spiritual leaders play an important role. ${ }^{161}$ AlRawi and colleagues proposed a conceptual model which combines traditional Arabic and Islamic Medicine and consists of three elements: spiritual healing, herbal medicine, and dietary practices. ${ }^{165}$ MuslimArabs believe that their bodies are a trust from God and as such they are accountable for how they look after their health. Therefore, the preservation and maintenance of health (eg, personal hygiene and nutrition) rather than the treatment of disease or restoration of health when it is lost is the goal. ${ }^{161,163,164}$ However, in case of illness, in addition to medications and surgery, prayers, visitations, seeking help from God, and rehabilitative psychospiritual healing interventions are pursued. ${ }^{161}$ The Qur'an is considered the source of direction for healing, guidance, and mercy in case of physical and psychological inflictions. ${ }^{162}$ Another important aspect of health and healing is the belief that God gave the knowledge and wisdom to health care professionals and thus they have the responsibility to 


\section{American Journal of Pharmaceutical Education 2019; 83 (4) Article 7228.}

improve health. Thus, the Arab culture based on Islamic teachings is not always fatalistic. There is the belief that God created a cure for every disease. However, other beliefs do exist such as that disease and human suffering are tests or punishments from God, and sickness is a source of purification from sin and an acceptance of fate at the end of life. ${ }^{164,165}$ Depending on their religious inclinations, some patients will not consume medicines that contain alcohol or pork products or any medicine during the fasting hours of Ramadan. Others will resort to reciting the Qur'an, visiting the mosque, and seeking a religious leader to help in their healing. ${ }^{144,161,162}$

Over the last century, religious scholars in the Arab world have strived to address ethical issues surrounding many modern medical discoveries such as organ donation and transplantation, artificial support to prolong life, assisted suicide and euthanasia, abortion, assisted reproductive technology, genetic engineering, and cloning. While rulings on these issues may be similar in many countries, it is important to know any specifics that are unique to each country. ${ }^{166,167}$

Beyond religion, cultural and mystical practices do exist in the Arab world, especially in rural areas. For example, cupping and cautery may still be seen in in Jordan, Saudi Arabia, and Yemen, as well as countries in North Africa. ${ }^{168}$ Amulets are also used in some countries to prevent "evil eye."169 Evil eye is invoked in health and healing especially when a child becomes sick or dies, or a woman is not able to carry a child. ${ }^{170}$

Life expectancy is improving in the Arab world. The disease burden in the region has shifted to more chronic than communicable diseases, similar to that in Western countries. ${ }^{171}$ Most of these diseases are caused by diet and lifestyle choices. However, in the poorer areas of the region, infectious diseases remain common.

Western Culture vs Arab Culture. Western culture is considered individualistic, personal goals are emphasized, self-identity is viewed apart from the group, the person is in control of his environment, time dominates interactions, interactions are informal, time is precise, and directness and openness characterize communication. ${ }^{147,172-175}$ Arab culture, on the other hand, is oriented toward collectivism, where group goals override self, self-identity is part of a group, the environment is controlled by fate, human interaction dominates, time is loose and informal, and a hierarchy of individuals and indirectness in interactions is emphasized. ${ }^{172-175}$ While it is important to keep all these aspects of the Arab culture in mind, it is important to recognize that not all interactions with people in the Arab world will follow such a collectivism orientation. Other aspects of the culture may favor taking time to establish a social relationship before the transaction of a business or health care encounter as compared to the "let's get down to business" mentality in the West. Also, while science is considered important, religion, traditions, and mysticism still play a role in explaining the physical world. ${ }^{147,172-175}$

Patriarchal Attitudes of Health Care Professionals and Educators. Based on the authors' experience, in the Arab world, the physician usually lies at the top of the professional hierarchy, as is true in many countries. The physician has a monopoly on decision-making in many aspects of health care. In general, the Arab culture is formal and patriarchal, which lends itself to this hierarchy. ${ }^{147,174,175}$ This hierarchy is also reflected in how professionals at universities and health care facilities act in a formal way in their interactions with other health care professionals and students. Some find it difficult to say, "I do not know," and do not accept being questioned or challenged by their students and subordinates. While educators and professionals are respectful to visitors from other countries, especially those from Western countries, at times their actions may be influenced by the "inferiority complex" referenced earlier ${ }^{130}$ or by what natives term the "Khawaja complex"176 (discussed later). So, visitors, especially those from Western countries, can help (without disturbing the existing culture) by exhibiting their informal way of interacting with colleagues and students and by showing humility, eg, stating when they do not know an answer, seeking the opinion of the host professionals, and giving their hosts opportunities to take the lead.

Verbal and Nonverbal Communication. In the Arab culture, body language is a very important aspect of communication. Thus, it is important for guests to be familiar with these unique aspects in order to effectively communicate a message and not insult anyone unintentionally. At the beginning and end of each visit, a handshake with the right hand is usually given while the left hand grasps the other person's elbow. The handshake usually lasts longer than it does in Western culture but tends to be less firm. ${ }^{147,173,177}$ When greeting close friends and family members, it is appropriate for a person to welcome them with a hug or two kisses on the cheek. During the greeting, it is usually a sign of respect to place your hand on your heart and give a slight bow. ${ }^{147,173,177}$ Conservative and veiled women may not choose to shake hands with men and will instead acknowledge them by either bowing their head or placing the right hand on the heart area. ${ }^{147,173}$

There are also certain ways for a person to position their body to avoid offending people. For example, they should not point the toe or heel or any part of their foot at a person and should not show the soles of their feet or use 


\section{American Journal of Pharmaceutical Education 2019; 83 (4) Article 7228.}

their foot to move an object. This is considered rude and disrespectful in the Arab culture as the foot is viewed as the lowest part of one's body and is forbidden to be seen or exposed. The feet should never be put on a coffee table, footstool, or desk. ${ }^{147,178}$ In addition, it is common courtesy in many countries for guests to remove their shoes before entering private homes. It is also important for a guest to know that when passing or receiving an object or food to do so with their right hand, as the left hand is sometimes viewed as "unclean" in certain parts of the Arab world. ${ }^{147,178}$

When it comes to verbal communication with Arabs, a guest must keep in mind that they believe that words hold power. ${ }^{147}$ Arab people do not enjoy talking in negative ways because of their belief that this is associated with negative results. Arabs love poetry and creative speech. They are also fond of flowery blessings. ${ }^{147,174}$ When discussing the unfortunate events of someone else, they tend to use euphemisms to describe how they are doing. Overall, these are general communication skills that translate from one Arab country to the next. However, as with any culture, guests should follow nonverbal cues from their host and treat each person as an individual.

The Inferiority Complex of the Khawaja/Ajnabi vs Distrust of Westerners. Because of the Western colonization of many Arab countries and the subjugation of natives that occurred over many years, there are still remnants of an inferiority complex among Arabs. This has led some people in the Arab world to emulate the West in many aspects of life and to value Westerners (Khawaja or Ajnabi) and their knowledge over that of natives of their own country and other Arabs. ${ }^{130,176}$ As a result, many Westerners who come to Arab countries to work are provided with incentives and benefits far beyond what is given to other nationalities. ${ }^{179}$ For example, North American and Western European citizens are paid much higher than those from countries such as the Philippines and India. However, these incentives have declined in recent years with the drop in oil prices and the focus on training their own citizens. ${ }^{180}$

Conversely, there is some element of mistrust of the West in many countries because of the colonial era, Western military action in the Arab and Muslim worlds, and the support of Israel (especially by the United States). There is also suspicion about the intentions of some Westerners when they engage with the Arab world. Therefore, clear intentions and transparency are recommended to build trust and alleviate any suspicisons. ${ }^{147,181}$

Work Hours and Work Habits. The concept of time is different in most of the Arab world compared to that in Western countries where "time is money." The concept of time in the Arab world revolves around events and time of the day. ${ }^{147,182}$ While it is important to be on time, visitors should not be offended if their guest is late. ${ }^{182}$ A typical work week is five days with Friday and Saturday off in most countries, except Lebanon where Saturdays and Sundays are off. Businesses are usually open from 9:30 a.m. to $1: 30$ p.m. and reopen from 3:30 p.m. to 6 p.m. During the month of Ramadan, businesses offer employees more flexible and/or fewer working hours.

In Saudi Arabia, the salary packages, including incentives, for Westerners are usually greater than or equal to those offered in their countries and other Arab countries. ${ }^{180}$ This is because there is no personal taxation, making net income much greater, which is one of the major benefits of working in Saudi Arabia. Office hours range from 8 a.m. until noon, then from 4 to 7 p.m. However, hospital staff work schedules similar to those of their Western counterparts. Friday is considered the Muslim day of rest, with work days usually being Sunday through Thursday. However, in Oman weekends are usually on Thursday and Friday.

The UAE also does not tax salaries; however, the cost of living there is increasing. ${ }^{183}$ Some companies offer attractive benefits to their employees such as 30 calendar days off per year and free annual flights back to their home country. Salaries in Kuwait are usually similar or higher than salaries in most Western countries, and there is no income tax. ${ }^{180}$ Friday is the official day off in Kuwait, with Thursday or Saturday off depending on the business.

\section{Recommendations for Culturally Sensitive Engage- ment When Hosting}

The aforementioned key culturally sensitive issues should be kept in mind when hosting faculty members and students from the Arab world in the United States. Taking cultural and religious preferences, issues of modesty (especially for female students), food restrictions, and other aspects discussed above into considerations prior to the guests' arrival are key to having a positive experience. Overall, the Arab countries discussed above are well known for their hospitality. Thus, reciprocal hospitality and a friendly attitude from their hosts will go a long way to making Arabic people feel welcome. In general, greetings and goodbyes are lengthy and sincere in the Arab culture. ${ }^{147}$ When greeting an Arab, the person who arrives first usually greets the other by saying "peace be upon you" (in Arabic, the phrase is Al-Salamu Alikum). When greeting a man, offer a warm handshake with the right hand only. As shared above, look for a cue from female visitors as to whether to offer a handshake. ${ }^{147}$ Engaging in "small talk" before beginning a professional encounter is common among Arabs. 


\section{American Journal of Pharmaceutical Education 2019; 83 (4) Article 7228.}

\section{CONCLUSION}

The Arab world shares many commonalities, but it is not monolithic. There is diversity among Arab peoples based on their cultural, national, and religious practices. Culturally sensitive engagement of Westerners with Arabs requires individuals and institutions to identify their own preconceptions and misconceptions and try to dispel them prior to engaging visitors or hosts. Understanding and respecting the history, cultural norms, and health and healing practices of a region is essential for positive engagement on a personal and professional level with the people. Identifying the needs of partnering institutions, government agencies, and individuals is key for successful and enriching experiences for both sides. When interacting with patients, the most important ways of building trust and rapport are to recognize the individuality of the patient and explore how his or her culture may impact the interaction. In general, courtesy and personal value are highly respected in the Arab world, so engaging in "small talk" with the patient prior to the initiation of personal or health questions that may be perceived as personally intrusive is recommended. Respect for the patient's and other individuals' modesty and privacy is important, as is gender sensitivity. Learning and respecting a patients' views about sickness, death, and dying also are important, as are becoming familiar with their religious practices, fasting and dietary customs, and views on contemporary medical problems. The Arab world is eager to further develop pharmacy education and practice, and many opportunities exist for rewarding engagements and even partnerships with their counterparts in the West.

\section{REFERENCES}

1. Prescott GM, Vu BN, Alsharif NZ, Prescott WA. Global health education in doctor of pharmacy programs in the United States. Am J Pharm Educ. 2017;81(2):Article 28.

2. Steeb DR, Overman RA, Sleath BL, Joyner PU. Global experiential and didactic education opportunities at US colleges and schools of pharmacy. Am J Pharm Educ. 2016;80(1): Article 7.

3. A report from the global pharmacy education special interest group. connecting global/international pharmacy education to the CAPE 2013 outcomes. https://www.aacp.org/sites/default/files/201710/GPE_CAPE_Paper_November_2015.pdf. Accessed March 3, 2019.

4. Alhamoudi A, Alnattah A. Pharmacy education in Saudi Arabia: the past, present and the future. Curr Pharmacy Teach Learn. 2018;10(1):54-60.

5. Kheir N, Zaidan M, Younes H, El Hajj M, Wilbur K, Jewesson PJ. Pharmacy education and practice in 13 Middle Eastern countries. $\mathrm{Am}$ J Pharm Educ. 2008;72(6):Article 133.

6. Al-Wazaify M, Malowe L, Absoul-Younes A, Al-Omran O. Pharmacy education in Jordan, Saudi Arabia and Kuwait. Am J Pharm Educ. 2006;70(1):Article 18.
7. Accreditation Council of Pharmacy Education. https://www.acpeaccredit.org/. Accessed March 3, 2019.

8. Canadian Council for Accreditation of Pharmacy Programs. http:// ccapp-accredit.ca/. Accessed March 3, 2019.

9. Accreditation Council for Pharmacy Education. Programs by

Status. https://www.acpe-accredit.org/accredited-programs-bystatus/. Accessed March 3, 2019.

10. Alsharif NZ, Brennan LF, Abrons JP, Chahine EB. An introduction to cultural sensitivity and global pharmacy engagement. Am J Pharm Educ. 2019;83(4):Article 7221.

11. UNESCO. Regional overview: Arab States. https:// en.unesco.org/unesco_science_report/arab-states?language $=$ en . Accessed March 3, 2019.

12. Arab Media: Globalization and emerging media industries. Mellor N, Ayish M, Dajani N, Rinnawi K. Polity Press. Cambridge, UK; 2011. https://books.google.com/books?id=GoU-

$\mathrm{NRhn} 1 \mathrm{agC} \& \mathrm{pg}=\mathrm{PT} 10 \& \mathrm{lpg}=\mathrm{PT} 10 \& \mathrm{dq} \# \mathrm{v}=$ onepage $\& \mathrm{q} \& \mathrm{f}=$ true. Accessed March 3, 2019.

13. Fattouh B, El-Katiri L. Energy subsidies in the Arab World in Arab human development report. UN development program, regional bureau for Arab states. 2012. http://www.undp.org/content/dam/rbas/ report/Energy\%20Subsidies-Bassam\%20Fattouh-Final.pdf Accessed March 3, 2019.

14. Arab League. League of Arab States. https://www.nationsonline.org/ oneworld/arab_league.htm. Accessed March 3, 2019.

15. Arab American Anti-Discrimination Committee. Lesson Plan: Arab culture and society. http://www.adc.org/education/educationalresources/. Accessed March 3, 2019.

16. Population Density (People per sq. km of land area: Arab World). The World Bank.https://data.worldbank.org/indicator/EN.POP. DNST?locations=1A\&view $=$ chart. Accessed March 3, 2019.

17. Levy-Rubin M. Non-Muslims in the Early Islamic Empire: From Surrender to Co-existence. Cambridge University Press; 2011.

18. A new wave of religious coexistence in the Arab world. Bahaiteaching.org. http://bahaiteachings.org/a-new-wave-ofreligious-coexistence-in-the-arab-world. Accessed March 3, 2019. 19. Gulf Cooperation Council. Encyclopedia Britannica. https:// www.britannica.com/topic/Gulf-Cooperation-Council. Last updated January 22, 2019. Accessed March 3, 2019.

20. The economic prospects and policy challenges in the GCC countries. International Monetary Fund. https://www.imf.org/ external/np/pp/eng/2016/102616b.pdf. Published October 16, 2016. Accessed March 3, 2019.

21. Cleveland WL, Bunton M. The Rise and Expansion of Islam, Chapter 1. In: History of the Modern Middle East. $5^{\text {th }}$ ed. Boulder, Colorado, Westview Press; 2013:1-17.

22. The golden age of Islam. Khan Academy. https:// www.khanacademy.org/humanities/world-history/medieval-times/ cross-cultural-diffusion-of-knowledge/a/the-golden-age-of-islam. Accessed March 3, 2019.

23. Cleveland WL, Bunton M. The development of Islamic Civilization to the Eighteenth Century. In: History of the Modern Middle East. $5^{\text {th }}$ ed. Boulder, Colorado, Westview Press; 2013:18-34. 24. Crusades: Effects of the Crusades. History Channel. https:// www.history.com/topics/crusades. Accessed March 3, 2019. 25. Szczepanski K. What effect did the Crusades have on the Middle East? https://www.thoughtco.com/crusades-effect-on-middle-east195596. Updated April 2, 2018. Accessed March 3, 2019.

26. Cleveland WL, Bunton M. The Ottoman and Safavid Empires: A New Imperial Synthesis. In: History of the Modern Middle East. $5^{\text {th }}$ ed. Boulder, Colorado, Westview Press; 2013:34-52. 


\section{American Journal of Pharmaceutical Education 2019; 83 (4) Article 7228.}

27. Cleveland WL, Bunton M. World War I and the End of the Ottoman Order, Chapter 9. In: History of the Modern Middle East. $5^{\text {th }}$ ed. Boulder, Colorado, Westview Press; 2013:137-158.

28. Sykes Picot Agreement 1916. Encyclopedia Britannica. https:// www.britannica.com/event/Sykes-Picot-Agreement. Accessed August 12, 218.

29. Cleveland WL, Bunton M. The Arab Struggle for Independence. Chapters 11 and 12. In: History of the Modern Middle East. $5^{\text {th }}$ ed.

Boulder, Colorado, Westview Press; 2013:179-220.

30. Metz HC. Persian Gulf States. Washington, DC: Federal

Research Division, Library of Congress. 1994. https://www.loc.gov/ item/93046476. Accessed March 3, 2019.

31. Cleveland WL, Bunton M. Changing patterns of war and peace: Egypt and Lebanon. Chapter 19. In: History of the Modern Middle East. $5^{\text {th }}$ ed. Boulder, Colorado, Westview Press; 2013:179-220.

32. Cleveland WL, Bunton M. The Middle East in the Arab struggle for independence. Chapters 11 and 12. In: History of the Modern Middle East. $5^{\text {th }}$ ed. Boulder, Colorado, Westview Press; 2013:218219.

33. Khan LA. The dictators of the Middle East. Huffpost. https:// www.huffingtonpost.com/liaquat-ali-khan/middle-east-dictators_ b_2191803.html. Updated January 26, 2013. Accessed

March 3, 2019.

34. Fatfta M. Rampant corruption in Arab states. Transparency Int. https://www.transparency.org/news/feature/rampant_corruption_ in_arab_states. Published February 21, 2018. Accessed March 3, 2019.

35. Kai-Hwa Wan F. Bill introduced to honor post-9/11 hate crime victims. NBC News. https://www.nbcnews.com/news/asian-america/ bill-introduced-honor-post-9-11-hate-crime-victims-n430266.

Published September 21, 2015. Accessed March 3, 2019.

36. Lichtblau E. Hate crimes against American Muslims most since post-9/11 era. NY Times. https://www.nytimes.com/2016/09/18/us/ politics/hate-crimes-american-muslims-rise.html. Published September 17, 2016. Accessed March 3, 2019.

37. The impact of $9 / 11$ on the Middle East. Middle East Policy Council. https://mepc.org/journal/impact-911-middle-east. Published Winter 2002. Accessed March 3, 2019.

38. Cleveland WL, Bunton M. The 2011 Arab Spring. Chapter 26. In: History of the Modern Middle East. $5^{\text {th }}$ ed. Boulder, Colorado, Westview Press; 2013:522-540.

39. Wilkens K. Higher education reform in the Arab world. The Brookings Project on U.S. Relations with the Islamic World. https:// www.brookings.edu/wp-content/uploads/2016/06/08_education_ reform_wilkins.pdf. Published 2011. Accessed March 3,

2019.

40. Abu-Orabi ST. Higher education \& scientific research in the Arab world. $15^{\text {th }}$ IAU General Conference Presentation.

Chulalongkorn University, Bangkok, Thailand. https:/www.hrk.de/ fileadmin/redaktion/hrk/02-Dokumente/02-07-Internationales/02-0715-Asien/02-07-15-1-Jordanien/Higher_Education_in_the_Arab_ World_Dr_Sultan.pdf. Published December 4, 2013. Accessed March 3, 2019.

41. Arabic language: Introduction to Arabic. http://al-bab.com/ arabic-language/arabic-language. Accessed March 3, 2019.

42. Culture: History of the Arabic Language. http:// arabicwithoutwalls.ucdavis.edu/aww/alifbaa_unit1/ ab1_culture_history.html. Accessed March 3, 2019. 43. Arabic language: Is Arabic difficult to learn? Al-bab.com. http:// al-bab.com/arabic-language/arabic-language-2. Accessed March 3, 2019.
44. Transport in the Arab league. Wikipedia. https:// en.wikipedia.org/wiki/Transport_in_the_Arab_League\#Highways. Accessed March 3, 2019.

45. Khouri R. The incredible development of the Gulf States. Harvard Kennedy School. Belfer Center. https://www. belfercenter.org/publication/incredible-development-gulf-states. Published August 27, 2008. Accessed March 3, 2019.

46. Halligan N. Smart Move: Automated transport in the Gulf. Arabian Business. http://www.arabianbusiness.com/smart-moveautomated-transport-in-gulf-648982.html. Published October 15, 2016. Accessed March 3, 2019.

47. Kabil N. 13 Unwritten rules of driving in Cairo. Published Mar 9, 2015. ScoopEmpire. https://scoopempire.com/13-unwritten-rules-ofdriving-in-cairo/. Accessed March 3, 2019.

48. Sharif A. A guide to driving in Lebanon. Culture Trip. https:// theculturetrip.com/middle-east/lebanon/articles/a-guide-to-drivingin-lebanon/. Updated January 2, 2018. Accessed March 3, 2019. 49. Sylvester P. Tips for driving in the UAE: Travel safety \& road rules. World Nomads. https://www.worldnomads.com/travel-safety/ middle-east/united-arab-emirates/driving-in-the-united-arabemirates-do-you-dare. Published February 1, 2018. Accessed March 3, 2019 .

50. Fisher M. Why are Dubai and Abu Dhabi's roads some of the world's most dangerous? The Atlantic. https:/www.theatlantic.com/ international/archive/2011/10/why-are-dubai-and-abu-dhabis-roadssome-of-the-worlds-most-dangerous/246816/. Published October 17, 2011. Accessed March 3, 2019.

51. Arabic Food. https://arabic-food.blogspot.com/p/about.html. Accessed March 3, 2019.

52. Arabic Food. Pinterest. https://www.pinterest.com/explore/ arabic-food/. Accessed March 3, 2019.

53. Salloum H. Foods of the Arabian Gulf Countries. ThingsAsian. http://thingsasian.com/story/foods-arabian-gulf-countries. Published October 3, 2006. Accessed March 3, 2019.

54. Alsharif NZ, et al. Current practices in global/international advanced pharmacy practice experiences (Part 1): home/host country or site and institution considerations. Am J Pharm Educ.

2016;80(3):Article 19.

55. Fulbright scholars program: pre-departure orientations. http:// www.cies.org/pre-departure-orientations. Accessed March 3, 2019. 56. The Center for Global Education. Study abroad student handbook worldwide. Studentsabroad.com. http:// www.studentsabroad.com/handbook/basic-health-and-safety.php? country =General. Accessed March 3, 2019.

57. Travel safety Middle East. World Nomads. https:// www.worldnomads.com/travel-safety/middle-east. Accessed March 3, 2019.

58. Travel Advisories. U.S. Department of State-Bureau of Consular Affairs. https://travel.state.gov/content/travel/en/traveladvisories/ traveladvisories.html.html. Accessed March 3, 2019.

59. The state of women's rights in the Arab World. The World Bank. http://www.worldbank.org/en/news/feature/2016/03/07/the-state-ofwomens-rights-in-the-arab-world. Published March 7, 2016.

Accessed March 3, 2019.

60. Cadei E. Many women in the Arab World are highly educated, but underemployed. HuffPost. https://www.huffingtonpost.com/ 2015/05/13/arab-world-women-education_n_7277296.html.

Published May 13, 2015. Accessed March 3, 2019.

61. The world's 100 most powerful Arab women. Arabian Business. http://www.arabianbusiness.com/the-world-s-100-most-powerfularab-women-541034.html. Accessed March 3, 2019. 


\section{American Journal of Pharmaceutical Education 2019; 83 (4) Article 7228.}

62. El-Swais M. Ten facts you didn't know about women in the Arab World. The World Bank. http://blogs.worldbank.org/arabvoices/tenfacts-about-women-arab-world. Published Friday 3, 2015. Accessed March 3, 2019.

63. Health in the Arab World: a view from within. Lancet. January 19, 2014. https://www.eurekalert.org/pub_releases/2014-01/1hit011614.php. Accessed March 3, 2019.

64. Embassy of the United Arab Emirates: Health Care. https:// www.uae-embassy.org/about-uae/health-care. Accessed March 3, 2019.

65. El Chaarani N. Dubai to have 12 new private hospitals by 2020. Gulf Business. http://gulfbusiness.com/dubai-12-new-privatehospitals-open-2020/. Published July 2017. Accessed March 3, 2019. 66. Increasing popularity of medical tourism in Jordan. MedHalt. http://www.medhalt.com/blog/increasing-popularity-medicaltourism-jordan. Published November 22, 2015. Accessed March 3, 2019.

67. Explained: Medical tourism in Egypt. MedHalt. http:// www.medhalt.com/blog/explained-medical-tourism-egypt. Published December 24, 2015. Accessed March 3, 2019.

68. Medical Tourism Index: Egypt. https://

www.medicaltourismindex.com/destination/egypt/. Accessed March 3, 2019 .

69. Lebanon: Welcome to Lebanon. PlacidWay. https:// www.placidway.com/country/79/Lebanon-Medical-Tourism. Accessed March 3, 2019.

70. Dubai launches world's first medical tourism portal. Gulf News. https://m.edarabia.com/dubai-launches-worlds-first-medicaltourism-portal/86232/. Published April 2016. Accessed March 3, 2019.

71. Health System Profile: Bahrain. Regional health systems observatory. World Health Organization. http://apps.who.int/ medicinedocs/documents/s17291e/s17291e.pdf. Published 2007. Accessed March 3, 2019.

72. Healthcare financing and expenditure. https://stats.oecd.org/ Index.aspx?DataSetCode=SHA. Accessed March 3, 2019. 73. World Health Organization. Health System Profile: Kuwait. http://apps.who.int/medicinedocs/documents/s17297e/s17297e.pdf. Published 2006. Accessed March 3, 2019.

74. Oman pharmaceutical country profile. http://www.who.int/ medicines/areas/coordination/OmanPSCP_Narrative2012-02-08Final.pdf. Published 2011. Accessed March 3, 2019.

75. Healthcare in Qatar. Expat Arrivals. http://www. expatarrivals.com/middle-east/qatar/healthcare-qatar. Accessed March 3, 2019.

76. Qatar's healthcare ranks fifth best in the world: report. Qatar Tribune. http://www.qatar-tribune.com/news-details/id/157185. Published March 6, 2016. Accessed March 3, 2019.

77. Cancer treatment is now free for all residents in Qatar: official. The Peninsula. https://www.thepeninsulaqatar.com/article/26/03/ 2018/Cancer-treatment-is-now-free-for-all-residents-in-QatarOfficial. Published March 26, 2018. Accessed March 3, 2019. 78. World Health Organization. Saudi Arabia: WHO statistical profile. http://www.who.int/gho/countries/sau.pdf?ua=1. Accessed March 3, 2019.

79. The Healthcare System of Saudi Arabia. Helen Ziegler \& Associates. https://www.hziegler.com/articles/healthcare-system-ofsaudi-arabia.html. Accessed March 3, 2019.

80. Albejaidi MF. Healthcare system in Saudi Arabia: an analysis of structure, total quality management and future challenges. $J$ Alt Perspective Soc Sci. 2010;2(2):794-818.
81. World Health Organization. United Arab Emirates: WHO statistical profile. http://www.who.int/gho/countries/are.pdf?ua $=1$. Accessed March 3, 2019.

82. MacLaren S. Mandatory health insurance in Dubai: All you need to know with time almost up. The National. https:// www.thenational.ae/business/money/mandatory-health-insurancein-dubai-all-you-need-to-know-with-time-almost-up-1.215018. Published June 9, 2016. Accessed March 3, 2019. 83. The U.A.E Healthcare Sector. U.S.-U.A.E. Business Council. http://usuaebusiness.org/wpcontent/uploads/2014/06/ HealthcareReport_Update_June2014.pdf. Accessed March 3, 2019. 84. Health system profile of Jordan, Regional Health Systems Observatory, World Health Organization Report. Published 2006. Accessed March 3, 2019.

85. UNICEF Report. https://www.unicef.org/jordan/ financial_impact_report_07_reduced.pdf. Accessed March 3, 2019. 86. American University of Beirut Medical Center: About us. http:// www.aubmc.org/aboutus/Pages/about.aspx. Accessed March 3, 2019.

87. Hôtel-Dieu de France Medical Center. http://www.hdf.usj.edu. lb/files_en/serv_med.php?serv_id=53. Accessed March 3, 2019. 88. Mezher M. The essential list of regulatory authorities in Asia. Regulatory Affairs Professionals Society. https://www.raps.org/ regulatory-focus $\% \mathrm{E} 2 \% 84 \% \mathrm{~A} 2 /$ news-articles $/ 2015 / 4 /$ the-essentiallist-of-regulatory-authorities-in-asia. Published April 6, 2015. Accessed March 3, 2019.

89. Ndomondo-Sigonda M, Miot J, Naidoo S, Dodoo A, Kaale E. Medicines regulation in Africa: current state and opportunities.

Pharm Med. 2017;31:383-397.

90. UAE Government Official Website. https:/government.ae/en/ information-and-services/health-and-fitness/health-authorities.

Accessed March 3, 2019.

91. Drug and Food Control. State of Kuwait Ministry of Health. https://www.moh.gov.kw/en/Online-Services/Drug-Food-Control. Accessed March 3, 2019.

92. Directorate General of Pharmaceutical Affairs and Drug Control. Ministry of Health, Sultanate of Oman. https://www.moh.gov.om/en/ web/dgpadc/introduction. Accessed March 3, 2019.

93. Saudi Food \& Drug Authority. https://www.sfda.gov.sa/En/ Pages/default.aspx, Accessed March 3, 2019.

94. Accreditation Council for Pharmacy Education. Directory of Programs with Certification. https://www.acpe-accredit.org/pdf/ISP/ DirectoryofCertifiedPrograms.pdf. Published June 2017. Accessed March 3, 2019.

95. CCAPP. Accredited International Programs. http://ccappaccredit.ca/international-programs/list-of-international-programs/. Accessed March 3, 2019.

96. Hamouda A, Al-Rousan RM, Alkhateeb FM. Pharmacy education in the Palestinian territories. Am J Pharm Educ. 2015;79(1):Article 3.

97. Al-Jumaili A, Hussain SA, Sorofman B. Pharmacy in Iraq: history, current status, and future directions. Am J Health-Syst Pharm. 2013;70:368-372.

98. Nour SA. Pharmacy Education in Egypt. J Pharm Res. 2018;1(5). https://medwinpublishers.com/OAJPR/

OAJPR16000127.pdf. Accessed March 3, 2019.

99. El-Jardali F, Jamal D, Jaafar M, Rahal Z. Analysis of health professionals migration: a two-country case study for the United Arab Emirates and Lebanon. http://www.who.int/hrh/migration/ Case_study_UAE_Lebanon_2008.pdf. Published 2008. Accessed March 3, 2019. 


\section{American Journal of Pharmaceutical Education 2019; 83 (4) Article 7228.}

100. Kheir N. An Arab pharmacy spring: taking matters in their own hands. Int J Clin Phar. 2013;35(5):665-667.

101. ASHP. Residency Programs. https://accred.ashp.org/aps/pages/ directory/residencyProgramSearch.aspx. Accessed March 3, 2019. 102. School of Pharmacy Jordan University. http://

pharmacy.ju.edu.jo/Home.aspx. Accessed March 3, 2019.

103. Faculty of Pharmacy Jordan University of Science and Technology. www.just.edu.jo/FacultiesandDepartments/

FacultyofPharmacy/Departments/ClinicalPharmacy/Pages/ welcome.aspx. Accessed March 3, 2019.

104. Al-jedai A, Qaisi S, Al-Meman A. Pharmacy practice and the health care system in Saudi Arabia. Can J Hosp Pharm.

2016;69(3):231-237.

105. Al-Wazaift M, Matowe L, Albsoul-Younes A, Al-Omaran OA. Pharmacy education in Jordan, Saudi Arabia and Kuwait. Am J Pharm Educ. 2006;70(1):Article 18.

106. Density of Pharmaceutical personnel (total number per 1000 population, latest available data). World Health Organization Global Observatory (GHO) data. https://www.who.int/gho/ health_workforce/pharmaceutical_density_text/en/. Accessed March 3, 2019.

107. Nazer LH, Tuffaha H. Health care and pharmacy practice in Jordan. Can J Hosp Pharm. 2017;70(2):150-155.

108. Abdel-Latif MM, Sabra K. Clinical pharmacy practice in Egyptian hospitals. Am J Health-Syst Pharm. 2016;73:e63-66. 109. Al-Jedai A, Qaisi S, Al-Meman A. Pharmacy practice and the health care system in Saudi Arabia. Can J Hosp Pharm.

2016;69(3):231-237.

110. Chahine EB. Clinical pharmacy education and practice in Lebanon. ACCP Int Clin Pharmacist. 2011;1(3):3-4.

111. Al-Worafi YM. The challenges of pharmacy education in Yemen. Am J Pharm Educ. 2014;78(8):Article 146.

112. Chamoun NR, Saad AH, Btaiche IF, Zalloua PA. Experience with clinical pharmacy implementation: bridging a gap between academia and practice in Lebanon. ACCP Int Clin Pharmacist. 2016;6(2):1-2.

113. Kheir N, Fahey M. Pharmacy practice in Qatar: challenges and opportunities. South Med Rev. 2011;4(2):92-96.

114. BPS certification stats by location. Board of Pharmacy Specialties website. https://portalbps.cyzap.net/dzapps/dbzap.bin/ apps/assess/webmembers/managetool? webid $=$ BPS \& pToolCode $=$ certrecord $\&$ RecCmd $=$ StatsByLocation $\& p$ Print $=$ Yes. Accessed March 3, 2019.

115. Cleveland Clinic Abu Dhabi: Pharmacy. https://

www.clevelandclinicabudhabi.ae/en/patients-and-visitors/facilities/ pharmacy/pages/default.aspx. Accessed March 3, 2019.

116. Katoue MG, Awad AI, Schwinghammer TL, Kombian SB. Pharmaceutical care in Kuwait: hospital pharmacists' perspectives. Int J Clin Pharmcist. 2014;36:1170-1178.

117. Mehralian G, Rangchian M, Javadi A, Peiravian F. Investigation on barriers to pharmaceutical care in community pharmacies: a structural equation model. Int J Clin Pharmacist. 2014;36:1087-1094.

118. Haloub R. Forecasting opportunities in the Middle Eastern market. Eye for Pharma. https://social.eyeforpharma.com/ commercial/forecasting-opportunities-middle-easternmarket. Published September 1, 2010. Accessed March 3, 2019.

119. Alsaddique A. Future of the pharmaceutical industry in the GCC countries. Integr Mol Med. 2017;4(4):1-3. http://

www.oatext.com/pdf/IMM-4-296.pdf. Accessed March 3, 2019.
120. United Arab Emirates pharmaceuticals \& healthcare report. BMI Research. https://www.bmiresearch.com/united-arab-emirates. Accessed March 3, 2019.

121. Khan TM, Suleiman A, Emeka P, Aljadhey H. Pharmaceutical pricing policies and procedures in Saudi Arabia: a narrative review. Ther Inn Reg Sci. 2015;1-5.

122. Chui C. Middle East: The new promised land for pharma? HIS Markit. https://ihsmarkit.com/research-analysis/middle-east-thenew-promised-land-for-pharma.html. Published February 27, 2015. Accessed March 3, 2019.

123. Health regulation worldwide. Middle East. http:// www.healthregulation.org/Continent.aspx .name = middle-east. Accessed March 3, 2019.

124. Dubai International Pharmaceutical \& Technology Conference \& Exhibition. http://duphat.ae/. Accessed March 3, 2019.

125. GCC Pharmacy Congress. http://www.gccpharmacongress. com/events/gcc-pharmacy-congress-2018/event-summaryee99e05ab8b144aeaf079b058dffb5a4.aspx. Accessed March 3, 2019.

126. Abu Dhabi Pharmacy Conference. http://adphac.ae/. Accessed March 3, 2019.

127. Lebanese Order of Pharmacists. http://www.opl.org.lb/ newdesign/details_events.php. Accessed March 3, 2019.

128. International Conference of Jordanian Faculties of Pharmacy. http://www.just.edu.jo/conferences/jipc/Pages/default.aspx. Accessed March 3, 2019.

129. Al-Zaytoonah University of Jordan and The University of Toledo International Pharmaceutical Conference. https:// www.zuj.edu.jo/ztipc2017/. Accessed March 3, 2019.

130. Said EW. Orientalism. New York, NY: Pantheon Books; 1978. 131. Shaheen JG. The TV Arab. Ohio: Bowling Green State University Popular Press.1984.

132. Shaheen JG. Reel Bad Arabs: How Hollywood Vilifies a People. New York: Olive Branch Press, Interlink Publishing Group. 2012 (originally published in 2001).

133. Shaheen JG. Guilty: Hollywood's Verdict on Arabs After 9/11. Northampton, MA: Olive Branch Press, Interlink Publishing Group. 2012.

134. Nawar E. What nobody tells you about Muslims and Arabs. HuffPost. https://www.huffingtonpost.com/essraa-nawar/what-nobody-tells-you-ab_b_6542156.html. Published February 3, 2015. Updated April 5, 2015. Accessed March 3, 2019.

135. Facts about Arabs and the Arab world. American Arab AntiDiscrimination Committee. http://www.adc.org/education/ educational-resources/. Published Nov 29, 2009. Accessed March 3, 2019.

136. Wingfield M, Karaman B. Arab stereotypes and American educators. http://www.adc.org/education/educational-resources/. Accessed March 3, 2019.

137. Desilver D, Masci D. World's Muslim population more widespread than you might think. Pew Research Center. http:// www.pewresearch.org/fact-tank/2017/01/31/worlds-muslimpopulation-more-widespread-than-you-might-think/. Published January 31, 2017. Accessed March 3, 2019.

138. Laird LD, DeMarrais J, Barnes LL. Portraying Islam and Muslims in MEDLINE: a content analysis. Soc Sci Med. 2007;65(12):2425-2439.

139. Aull F, Lewis B. Medical intellectuals: resisting medical Orientalism. J Med Humanit. 2004;25(2):87-108.

140. Purposeful global engagement in pharmacy education. $\mathrm{Am} J$ Pharm Educ. 2017;81(10). 


\section{American Journal of Pharmaceutical Education 2019; 83 (4) Article 7228.}

141. Campinah-Bacote J. The process of cultural competence in the delivery of healthcare services: a model of care. J Transcultural Nurs. 2002;13(3):181-184.

142. Berlin EA, Fowkes Jr, WC. A Teaching framework for CrossCultural Health Care. The Western J Med. 1983;139:934-938.

143. Islam fast facts. CNN Library. https://www.cnn.com/2013/11/

12/world/islam-fast-facts/index.html. Updated August 24, 2018.

Accessed March 3, 2019.

144. Alsharif NZ, Galt KA, Kasha TA. Health and healing practices for the Muslim community in Omaha-Nebraska. J Religion. Chapter 6, pp.150-168, 2011.

145. Health Care in Islamic History and Experience. EthnoMed. http://ethnomed.org/cross-cultural-health/religion/health-care-inislamic-history-and-experience. Published June 16, 2018. Accessed March 3, 2019.

146. Tristam P. Christians of the Middle East: Country-by-Country. https://www.thoughtco.com/christians-of-the-middle-east-2353327.

Published May 22, 2017. Accessed March 3, 2019.

147. Arab Cultural Awareness: 58 Factsheets. Office of the Deputy Chief of Staff for Intelligence. US Army Training and Doctrine Command. https://fas.org/irp/agency/army/arabculture.pdf. Accessed March 3, 2019.

148. Hussein S. Long-term care needs in Arab World. Social Care Workforce Research. King's College London, UK. $12^{\text {th }}$ Islamic Countries Conference on Statistical Sciences. Dec 19-22, 2012. Qatar University, Doha, Qatar. https://www.researchgate.net/publication/ 233996980_Long-term_care_needs_in_Arab_World. Accessed March 3, 2019.

149. Hussein S, Ismail M. Ageing and elderly care in the Arab region: policy challenges and opportunities. Ageing Int.

2017;42(3):274-289.

150. Miklancie MA. Caring for patients of diverse religious traditions: Islam, a way of life for Muslims. Home Hlth Nurse. 2007;25(6):413-417.

151. Al-Amoudi SM. Health empowerment and health rights in Saudi Arabia. Saudi Med J. 2017;38(8). https://www.ncbi.nlm.nih. gov/pmc/articles/PMC5556292/. Accessed March 3, 2019.

152. Okasha A, Karam E, Okasha T. Mental health services in the Arab World. World Psychiatry. 2012;11(1):52-54.

153. Despots are pushing the Arab World to become more secular. The Economist. 2017. https://www.economist.com/ middle-east-and-africa/2017/11/02/despots-are-pushing-the-arabworld-to-become-more-secular. Published November 2. Accessed March 3, 2019.

154. Davies C. Mideast women beat men in education, lose out at word. CNN. http://www.cnn.com/2012/06/01/world/meast/middle-

east-women-education/index.html. Published June 6, 2012. Accessed March 3, 2019.

155. Jalbout M. Unlocking the potential of educated Arab women. https://www.brookings.edu/blog/education-plus-development/2015/ 03/12/unlocking-the-potential-of-educated-arab-women/. Published March 12, 2015. Accessed March 3, 2019.

156. Luck T. Progress watch: Across the Arab world, a 'Women's Spring' Comes into View. The Christian Science Monitor. https:// www.csmonitor.com/World/Middle-East/2017/0809/Across-theArab-world-a-Women-s-Spring-comes-into-view. Published August 9, 2017. Accessed March 3, 2019.

157. Women in Politics: Algeria. European Parliamentary Research Service. http://www.europarl.europa.eu/eplibrary/ Algeria.pdf. Published November 25, 2013. Accessed March 3, 2019.
158. El-Behary H. Women's representation in new parliament highest in Egypt's history. Egypt Independent. http://www. egyptindependent.com/women-s-representation-new-parliamenthighest-egypt-s-history/. Published January 5, 2016. Accessed March 3, 2019.

159. Pearson M. Polls open in Saudi Arabia, first time women allowed to vote. CNN. https://www.cnn.com/2015/12/12/world/ saudia-arabia-women-vote/index.html. Published December 12, 2015. Accessed March 3, 2019.

160. Walton LM, Akram F, Hossain F. Health beliefs of Muslim women and implications for health care providers: Exploratory study on the health beliefs of Muslim women. J Hlth Ethics.

2014;10(2):Article 5.

161. Stacey A. Health in Islam (Part 1 of 4): A holistic Approach. https://www.islamreligion.com/articles/1878/health-in-islam-part-1/ Accessed March 3, 2019.

162. Stacey A. Health in Islam (Part 2 of 4): Quran is a healing. https:/www.islamreligion.com/articles/1891/health-in-islam-part-2/. Accessed March 3, 2019.

163. Stacey A. Health in Islam (Part 3 of 4): Diet and nutrition. https://www.islamreligion.com/articles/1892/health-in-islam-part-3/. Accessed March 3, 2019.

164. Stacey A. Health in Islam (Part 4 of 4): Fitness and exercise. https://www.islamreligion.com/articles/1904/health-in-islam-part-4/. Accessed March 3, 2019.

165. AlRawi S, Kidir A, Elnashar MS, Abdelrahim HA, Fetters MD. Traditional Arabic \& Islamic medicine: validation and empirical assessment of a conceptual model in Qatar. BMC Complement Altern Med. 2017;17(1):157.

166. Padela AI. Islamic medical ethics: A Primer. Bioethics. 2007 Mar;21(3):169-178.

167. Gatrad AR, Sheikh A. Medical ethics and Islam: principles and practice. Arch Dis Child. 2001 Jan;84(1):72-75.

168. Doumato EA. Getting God's Ear: Women, Islam and Healing in Saudi Arabia and the Gulf. New York, 2000.

169. Ventuta J, Popper-Giveon A, Abu Rabia A. Materialized Beliefs: 'Industrialized' Islamic amulets. Visual Ethnography. 2014;3(3):30-47.

170. Harfouche JK. "The Evil Eye and Infant Health in Lebanon." In The Evil Eye: A Casebook. Ed. Dundes A. Madison, Wisconsin. 1992. 86-106.

171. Mokdad A. Arab countries living longer but battling chronic disease. Institute for Health Metrics and Evaluation. http://www.healthdata.org/news-release/arab-countries-livinglonger-battling-chronic-disease. Accessed March 3, 2019.

172. Royeen M, Crabtree JL. Culture in Rehabilitation: From Competency to Proficiency. $1^{\text {st }}$ ed. Pearson. London, England. 2005.

173. Buda R, Elsayed-Elkhouly SM, Cultural differences between Arabs and Americans: individualism-collectivism revisited. J CrossCultural Psych. May 1998.

174. Reynolds DF. The Cambridge companion to modern Arab culture. Cambridge University Press. 2015.

175. Zafar S, Zafar J. Informality - A Unique American value. Living American. http://www.vidaamericana.com/english/ informality.html. Accessed March 3, 2019.

176. Montaser K. The Muslim World's inferiority complex. Gatestone Institute. 2011. https://www.gatestoneinstitute.org/2111/ muslim-world-inferiority-complex. Published May 11, 2011. Accessed March 3, 2019. 


\section{American Journal of Pharmaceutical Education 2019; 83 (4) Article 7228.}

177. The essential guide to Arabic customs \& culture for the business traveler. https://www.uklinkology.co.uk/wp-content/uploads/2014/ 11/Arabic_Customs.pdf. Accessed March 3, 2019.

178. Gammell C. Arab culture: The insult of the shoe. The Telegraph. https://www.telegraph.co.uk/news/worldnews/ middleeast/iraq/3776970/Arab-culture-the-insult-of-the-shoe.html. Accessed March 3, 2019.

179. Salary gap between nationalities in the GCC revealed. Emirates Woman. 2017. http://emirateswoman.com/salary-gap-betweennationalities-in-the-gcc/. Published March 21. Accessed March 3, 2019.

180. Anderson R. The Gulf business salary survey 2018. http:// gulfbusiness.com/gulf-business-salary-survey-2018/. Accessed March 3, 2019.
181. Salbi Z. It's complicated: What people in the Middle East say in private about the West. https://womenintheworld.com/2015/05/26/ what-people-in-the-middle-east-are-saying-in-private-about-thewest/ May 26, 2015. Accessed March 3, 2019.

182. Hodgetts R. Knowing Arab view of time is crucial in business dealings. Sun Sentinel. http://articles.sun-sentinel.com/ 1992-09-07/business/9201200235_1_business-personarab-countries-meetings. Published Sept 7, 1992. Accessed March 3, 2019.

183. Haza R. Stagnant salaries and high cost of living have UAE expats job-seeking. The National. https:/www.thenational.ae/uae/ stagnant-salaries-and-high-cost-of-living-have-uae-expats-jobseeking-1.617239. Updated August 6, 2017. Accessed March 3, 2019 